\title{
Addition of Pasture Plant Essential Oil in Milk: Influence on Chemical and Sensory Properties of Milk and Cheese
}

\author{
G. Tornambé, ${ }^{\star} \dagger$ A. Cornu, ${ }^{\ddagger} \ddagger$ I. Verdier-Metz,§ P. Pradel,\# N. Kondjoyan,‡ G. Figueredo, $\|$ \\ S. Hulin, ๆ and B. Martin ${ }^{\star 1}$ \\ *INRA, UR1213 Unité de Recherches sur les Herbivores, Theix, F-63122 Saint-Genès-Champanelle, France \\ †Dipartimento S.En.Fi.Mi.Zo, Facoltà di Agraria, Universita degli Studi di Palermo, Palermo, Italy \\ †INRA, UR370 Unité de Recherches sur la Qualité des Produits Animaux, Theix, F-63122 Saint-Genès-Champanelle, France \\ §INRA, UR545 Unité de Recherches Fromagères, F-15000 Aurillac, France \\ \#INRA, UE373 Unité Expérimentale de Marcenat, F-15190 Marcenat, France \\ |Laboratoire de Chimie des Huiles Essentielles, Université Blaise Pascal, Les Ceseaux, F-63177 Aubière, France \\ ๆComité Interprofessionnel des Fromages du Cantal, F-15000 Aurillac, France
}

\begin{abstract}
The aim of this experiment was to study the effect of the addition, to milk, of an essential oil (EO) obtained from the hydrodistillation of plants collected from a mountain natural pasture on the milk and cheese sensory properties. The EO was mainly composed of terpenoid compounds (67 of the 95 compounds identified) as well as ketones, aldehydes, alcohols, esters, alkanes, and benzenic compounds. In milk, the addition of this $\mathrm{EO}$ at the concentration of $0.1 \mu \mathrm{L} / \mathrm{L}$ did not influence its sensory properties, whereas at $1.0 \mu \mathrm{L} / \mathrm{L}$, sensory properties were modified. In cheeses, the effect of adding EO into milk was studied in an experimental dairy plant allowing the production of small Cantal-type cheeses $(10 \mathrm{~kg})$ in 3 vats processed in parallel. The control $(\mathrm{C})$ vat contained $110 \mathrm{~L}$ of raw milk; in the other 2 vats, $0.1 \mu \mathrm{L} / \mathrm{L}$ (EO1) or $3.0 \mu \mathrm{L} / \mathrm{L}$ (EO30) of EO were added to $110 \mathrm{~L}$ of the same milk. Six replicates were performed. After 5 mo of ripening, chemical and sensory analyses were carried out on the cheeses, including determination of the volatile compounds by dynamic headspace combined with gas chromatography-mass spectrometry. The EO did not influence the sensory properties of the cheeses at the lower concentration (EO1). However, the EO30 cheeses had a more intense odor and aroma, both characterized as "mint/chlorophyll" and "thyme/oregano." These unusual odors and aromas originated directly from the EO added. In total, 152 compounds desorbing from cheese were found, of which 41 had been added with the EO; in contrast, 54 compounds of the $\mathrm{EO}$ were not recovered in the cheese. Few volatile compounds desorbing from cheeses, other than the added compounds, were affected by EO addi-
\end{abstract}

Received March 1, 2007.

Accepted September 7, 2007.

${ }^{1}$ Corresponding author: bmartin@clermont.inra.fr tion. Among them, 2-butanol, propanol, and 3-heptanone suggested a slight effect of the EO on lipid catabolism. The antimicrobial activity of terpenes is not or is only marginally involved in the explanation of the influence of the botanical composition of the meadows on the pressed cheeses sensory properties.

Key words: terpene, sensory property, essential oil, volatile compound

\section{INTRODUCTION}

Several trials have been conducted in Europe in recent years to describe and analyze the effect of the botanical diversity of forages fed to animals on the sensory characteristics of various types of cheeses (Martin et al., 2005a). A specific interest was lent to this topic because the botanical composition of the meadows is partly linked to environmental conditions and is therefore an important component of "terroir," a notion at the basis of the Protected Denomination of Origin (PDO) labeling. Trials performed in summer when cows graze different highland meadows on French Beaufort or Abondance cheeses (Buchin et al., 1999; Martin et al., 2005b) or Swiss Gruyere cheese (Bosset et al., 1999) indeed showed differences in cheese sensory properties according to the botanical composition of meadows. Bugaud et al. (2001b) were able to describe some associations between the botanical composition of the meadows and the sensory features of Abondance cheeses.

To explain these links, the authors suggested some possible effects of fatty acids and plasmin that varied greatly from one situation to another (Bugaud et al., 2001a). Dumont and Adda (1978) also proposed that terpenes may play a role. These plant-specific molecules have recognizable aromatic properties when concentrated and are the major components of essential oils (EO). They abound in certain species, dicotyledons in particular, and terpene concentration in forage is 
mainly governed by its botanical composition: graminaceae-based forages are terpene-poor, whereas mountain-diversified pasture forages with a large number of dicotyledons including aromatic species are terpenerich (Mariaca et al., 1997; Bugaud et al., 2001b; Cornu et al., 2001). These molecules very rapidly pass into the milk (Viallon et al., 2000) with some minor alterations and are found in cheese in much greater quantities when the animals are fed dicotyledon-rich natural grass forage compared with when they are fed concentratebased rations (Moio et al., 1996) or monospecific forage (Bosset et al., 1999; Viallon et al., 1999; Carpino et al., 2004). However, it appears that changes in terpene concentration in cheese are not sufficient to exert any marked direct effect on cheese flavor (Moio et al., 1996; Verdier-Metz et al., 2000; Bugaud et al., 2001b). Nevertheless, because of their antimicrobial properties (Hammer et al., 1999; Burt, 2004), terpenes may have an indirect impact on cheese sensory properties by modifying the dynamics or the activity of the microbial ecosystem during cheese making and ripening. This hypothesis results from indirect observations in several trials on hard cooked cheeses (Buchin et al., 1999; Bugaud et al., 2001b; Martin et al., 2005b), in which the cheeses richest in terpenes had greater overall scores for milder flavors such as nutty or sweet, and lower scores for attributes such as animal, spicy, cabbage, toasted, fermented vegetable, acid, and pungent. These sensory differences could be related to differences observed in the volatiles desorbing from the cheeses: terpene content was negatively correlated to the presence of other volatile components obtained from the protein breakdown by microbial enzymes. Nevertheless, this indirect effect of terpenes on cheese sensory properties via a modification of the microbial development or activity has never been tested directly in specifically designed trials. Such was the aim of this experiment, in which we added various quantities of an EO obtained from the hydrodistillation of plants collected from a mountain natural pasture into milk before cheese making of Cantal-type cheeses.

\section{MATERIALS AND METHODS}

\section{Grassland Botanical Composition and EO Extraction}

Five times in 3 consecutive weeks in July 2003, fresh herbage was cut from one naturally diversified mountain grassland located in the Cantal area (France) at 1,100 m elevation. Forty-six plant species were identified in the plot, 14 poaceaes and 32 dicotyledons. Their relative contribution to the total number of plants was 44 and 56\%, respectively. The main species identified and their relative contributions were Festuca rubra,
14.5\%; Agrostis capillaris, 9.5\%; Carex caryophyllea, 6.2\%; Hieracium pilosella, 7.8\%; Thymus pulegioides, 5.5\%; Gentiana lutea, $5.0 \%$; Stachys officinalis, $4.8 \%$; Festuca nigrescens, 4.8\%; Achillea millefolium, 4.2\%; Helianthemum nummularium, 3.2\%; Galium verum, 3.2\%; Meum athamanticum, 2.7\%; and Anthoxanthum odoratum, $2.5 \%$. After each cutting, a rough removal of the poaceae plants was performed and the dicotyledon plants were kept in nylon vacuum bags and preserved at $-18^{\circ} \mathrm{C}$ for 2 mo. The plant material was extracted by steam distillation in a Clevenger apparatus for $3 \mathrm{~h}$. Eight successive runs with $2 \mathrm{~kg}$ of frozen plant material made it possible to obtain $15 \mathrm{~mL}$ of pooled EO.

The EO was analyzed using a gas chromatograph (model 6890 Hewlett-Packard, Agilent, SRA Instruments, Le Raincy, France) coupled to a mass spectrometer (model 5873, Hewlett-Packard) equipped with an HP5 column $(30 \mathrm{~m} \times 0.25 \mathrm{~mm}$, film thickness, $0.25 \mu \mathrm{m})$ programmed from $50^{\circ} \mathrm{C}(5 \mathrm{~min})$ to $300^{\circ} \mathrm{C}$ at $5^{\circ} \mathrm{C} / \mathrm{min}$, followed by a 5 -min hold. The carrier gas was helium $(1.1 \mathrm{~mL} / \mathrm{min})$; injection was set in the split mode (1/ 10). Injector and detector temperatures were 250 and $280^{\circ} \mathrm{C}$, respectively. Ionization was by electron impact at $70 \mathrm{eV}$; electron multiplier was $2,200 \mathrm{~V}$; and the ion source temperature was $230^{\circ} \mathrm{C}$. Mass spectral data were acquired in the scan mode in the $\mathrm{m} / \mathrm{z}$ range of 33 to 450 .

Identification was carried out by calculating retention indices and comparing mass spectra with data banks published by Adams (1995) and McLafferty and Stauffer (1989). Peak areas were quantified as a percentage of the total ion count. Peaks contributing to the total area by more than $0.01 \%$ were identified.

\section{Trial 1: Influence of EO Addition on the Milk Sensory Properties}

The milk from the morning milking of 3 Holstein cows fed a maize (Zea mays L.) silage-based diet was collected twice, $2 \mathrm{~d}$ apart, for milk sensory analyses. On average, this milk contained $5.2 \%$ fat, $3.6 \%$ protein, $4.8 \%$ lactose, and 125,000 somatic cells $/ \mathrm{mL}$. The EO described previously was added to this milk (control, C) in 2 different concentrations: $0.1 \mu \mathrm{L} / \mathrm{L}$ (EO1) and $1.0 \mu \mathrm{L} / \mathrm{L}$ (EO10). Sensory evaluations, consisting of a triangular test, were conducted in a red light environment by a panel of 16 untrained assessors. The full-fat raw milk samples were served at room temperature $\left(22^{\circ} \mathrm{C}\right)$. The test consisted of comparing $\mathrm{C}$ and EO1 milk and $\mathrm{C}$ and EO10 milk in 2 sessions. During each session 4 tests were performed, with the 2 comparisons being repeated to obtain 61 answers for each of the comparisons. For every test, 3 samples of milk ( 2 identical and 1 unique) were presented simultaneously to different 
assessors in 3 opaque white plastic glasses. Every assessor had to identify the unique sample from among the 3 and describe the magnitude of the differences perceived on a structured scale from 1 (very small) to 5 (very high). Results are expressed as a percentage of correct answers.

\section{Trial 2: Influence of EO Addition on Chemical and Sensory Properties of Cheese}

Animals. Twenty-four cows (Montbéliarde $\mathrm{n}=13$ and Holstein $\mathrm{n}=11$ ) calving between November 15 and January 10 and producing, on average, $20.5 \mathrm{~kg}$ of milk/ $\mathrm{d}$ with $3.61 \%$ fat and $2.97 \%$ protein were used in this experiment. From March 15 until April 20, cows were fed a terpene-poor diet based on rye-grass silage fed ad libitum and $6 \mathrm{~kg}(\mathrm{DM}) / \mathrm{cow}$ per d of cocksfoot hay. This diet was completed with, on average, $5.9 \mathrm{~kg}(\mathrm{DM})$ of a commercial mixture based on cereals and soybean meal distributed individually according to each cow's milk yield.

Cheese Making. During the final 3 wk of the experiment, twice a week, the raw milk from the evening milking was stored at $4^{\circ} \mathrm{C}$ and pooled with the milk collected from the following morning's milking. In total, $330 \mathrm{~L}$ of this milk was distributed into 3 vats. Each $200-\mathrm{L}$ vat allowed the production of 1 small Cantaltype cheese (about $10 \mathrm{~kg}$ instead of $40 \mathrm{~kg}$ ). Every cheese making day (6 in total), 3 vats were manufactured in parallel. One vat contained $110 \mathrm{~L}$ of full-fat raw milk (control), and the other 2 consisted of $110 \mathrm{~L}$ of the same milk with 0.1 (EO1) or $3.0 \mu \mathrm{L} / \mathrm{L}$ (EO30) of EO. Previous studies (A. Cornu, unpublished data) showed that the terpenes desorbing from milks obtained from cows fed a mountain-diversified hay were similar to those desorbing from milk with $1.0 \mu \mathrm{L} / \mathrm{L}$ of this EO added, which correspond to the EO1 samples of this experiment. In addition, previous work (A. Cornu, unpublished data) showed that the terpenes desorbing from milks obtained from cows fed a mountain-diversified pasture composed of $15 \%$ aromatic plants was similar to the terpenes desorbing from milk with $0.1 \mu \mathrm{L} / \mathrm{L}$ of this EO added. We have chosen the EO30 concentration to test an extreme situation. The total amount of terpenes desorbing from this milk was about 3 times greater than the total amount of terpenes desorbing naturally from milk obtained from cows fed a mountain-diversified pasture. Considering that the proportion of aromatic plants in the grassland may exceed $15 \%$, particularly in Mediteranean grasslands, and that EO may be added in the cow's diets to modify rumen microbial fermentations (Calsamiglia et al., 2007), we hypothesized that the EO30 concentration could be found in practice.
The EO was added just before cheese making after the milk had been heated to $33^{\circ} \mathrm{C}$. Then, the milk was inoculated with $0.2 \mathrm{~g}$ of a lyophilized mesophilic starter culture (Flora Danica Direct, Chr. Hansen, Arpajon, France) reconstituted in sterile skimmed milk (100 g/ $\mathrm{L})$ with a ripening starter $(2 \mathrm{~mL}$ of Monilev and $1.5 \mathrm{~mL}$ of Penbac, Laboratoire Interprofessionnel de Production, Aurillac, France) and with $0.33 \mathrm{~g} / \mathrm{kg}$ of rennet (Beaugel 500, Villefranche sur Saône, France) containing $520 \mathrm{mg}$ of active chymosin/L. Forty-five minutes later, the curd was cut for 5 min to produce pellets 5 to $6 \mathrm{~mm}$ in diameter. The curd-whey mixture was then blended for $12 \mathrm{~min}$ and left to stand for $7 \mathrm{~min}$. After draining the whey, the curd was placed in a pressing tray where it was pressed, cut in $15-\mathrm{cm}$ cubes, and turned 12 times in approximately $3 \mathrm{~h}$ to reach $50 \% \mathrm{DM}$. After pressing, the curd cubes were left to drain for 24 $\mathrm{h}$ at $20^{\circ} \mathrm{C}$ and were pounded into grains $20 \mathrm{~mm}$ in diameter. The mixture was salted with $20 \mathrm{~g} / \mathrm{kg}$ of dry salt and left to stand for $6 \mathrm{~h}$ at $20^{\circ} \mathrm{C}$ before 1 cheese per vat was formed in a cloth mold and pressed for 24 $\mathrm{h}$ at $13^{\circ} \mathrm{C}$. The cheeses were placed in a ripening cellar for $5 \mathrm{mo}$ at $10^{\circ} \mathrm{C}$ and $95 \%$ minimum relative humidity.

Milk Analyses. $\mathrm{pH}\left(\right.$ at $20^{\circ} \mathrm{C}$ ) and protein, fat, and lactose contents (infrared method, Milkoscan 4000, Foss System, Hillerød, Denmark), SCC (Fossomatic 5000, Foss System; IDF, 1997), and butyric spore count were assessed in a representative sample of each vat. The FFA content of milk was measured by the copper soap method (Jellema, 1991).

The Cinac system (Ysebaert Dairy Division, Frepillon, France) was used to measure the acidification properties of the milk (Corrieu et al., 1989). pH measurements were taken every $10 \mathrm{~min}$ for $72 \mathrm{~h}$ as per dynamic and static $\left(32^{\circ} \mathrm{C}\right)$ temperature kinetics. Dynamic kinetics reproduces the thermal cycle of Cantal cheese making: $10 \mathrm{~min}$ at $33^{\circ} \mathrm{C}, 35 \mathrm{~min}$ at $32^{\circ} \mathrm{C}, 30 \mathrm{~min}$ at $31^{\circ} \mathrm{C}$, $3 \mathrm{~h}$ at $30^{\circ} \mathrm{C}, 13 \mathrm{~h}$ and $20 \mathrm{~min}$ at $22^{\circ} \mathrm{C}, 8 \mathrm{~h}$ at $20^{\circ} \mathrm{C}, 22$ $\mathrm{h}$ and $20 \mathrm{~min}$ at $17^{\circ} \mathrm{C}$, and $24 \mathrm{~h}$ at $13^{\circ} \mathrm{C}$. The 3 milks (C, EO1, and EO30) were studied with the starters used for cheese making.

Cheese Analyses. Dry matter content was determined by heating at $103^{\circ} \mathrm{C}$ for $24 \mathrm{~h}$. The fat content of the cheeses was measured by using the butyrometric method (IDF, 1997). Total nitrogen, water-soluble nitrogen, and phosphotungstic-acid-soluble nitrogen were measured using the methods described by Ardö (1999).

All ripened cheeses were submitted to 12 trained assessors who scored the intensity of 38 attributes ( 7 for texture, 7 for flavor, 11 for odor, 13 for aroma) on a 0 (very low) to 7 (very high) structured scale. Two preliminary sensory test sessions were carried out by assessors 
using these experimental cheeses to define specific attributes for these cheeses.

For volatile compound analyses, wrapped cheese cuts were allowed to thaw overnight at room temperature before the bags were opened. Pieces of about $5 \mathrm{~g}$ were taken from the middle of the cuts and rapidly ground in a mortar with $10 \mathrm{~g}$ of anhydrous sodium sulfate. Five grams of the resulting powder was deposited on $0.15 \mathrm{~g}$ of glass wool in a cylindrical $40-\times 120$-mm glass extraction cartridge (Ets Mallières Frères, Aubière, France). The volatile compounds were extracted by a dynamic headspace method with an automatic Tekmar LSC2000 system (Tekmar, Cincinnati, $\mathrm{OH}$ ) under the following conditions: purge $30 \mathrm{~min}$ at room temperature $\left(21^{\circ} \mathrm{C}\right)$ by a $65 \mathrm{~mL} / \mathrm{min}$ helium flow, trap on Tenax, dry purge 3 min, desorb preheat $175^{\circ} \mathrm{C}$, desorb $5 \mathrm{~min}$ at $180^{\circ} \mathrm{C}$, and cryofocusing at $-150^{\circ} \mathrm{C}$ in the gas-chromatograph inject port. The volatile compounds were separated using a gas chromatograph (model 5890, Hewlett Packard, Les Ulis, France, Agilent) and a Supelco capillary column (60 m $\times 0.32 \mathrm{~mm}$, Supelco, Gland, Switzerland) coated with a $1-\mu \mathrm{m}$-thick SPB5 stationary phase. The injection port was heated for $2 \mathrm{~min}$ at $225^{\circ} \mathrm{C}$, the carrier gas was helium at $1 \mathrm{~mL} / \mathrm{min}$, and the oven temperature program was $40^{\circ} \mathrm{C}$ for $5 \mathrm{~min}$, increasing at $3^{\circ} \mathrm{C} / \mathrm{min}$ up to $230^{\circ} \mathrm{C}$, and held for $2 \mathrm{~min}$. The volatile compounds were detected using a mass selective detector (model 5971A, Hewlett Packard, Agilent) operating at $70 \mathrm{eV}$ electron impact. Identifications were proposed by comparing the experimental data to the published mass spectral (Wiley 275K, 1995; NIST/EPA/NIH, 1996) and retention index (Kondjoyan and Berdagué, 1996) databases. Integrations were performed for each component using a selected ion whose peak was not deformed by a coelution.

\section{Data Analysis}

The data were processed by ANOVA using the GLM procedure (version 6.12, SAS Institute, Inc., Cary, NC). For milk composition and acidification properties and for cheese composition and rheological properties, the statistical model included the effect of the treatment. For sensory data, the statistical model included the effect of the treatment, the assessor, and the treatment $\times$ assessor interaction. For the milk triangular test, we used the values from the table calculated as binomial law of parameter $P=1 / 3$ with $\mathrm{n}$ repetitions (AFNOR, 1983).

\section{RESULTS AND DISCUSSION}

\section{EO Composition}

Ninety-five volatile compounds, representing $75.4 \%$ of the total area, were identified in the EO (Table 1), with each of the remaining peaks accounting for less than $0.01 \%$. The most abundant family was the terpenoid family with 14 monoterpenes, 24 monoterpene derivatives, 18 sesquiterpenes, and 11 sesquiterpene derivatives, together accounting for $61.1 \%$ of the total peak area. Beside terpenes, the 7 benzenic compounds identified account for $12 \%$ of the total peak area and are also commonly found in plant EO. The benzenic compounds dill apiole and carvacrol were the most abundant in the $\mathrm{EO}$ after the sesquiterpene germacrene D. The remaining compounds (1 ketone, 6 aldehydes, 4 alcohols, 3 esters, and 7 alkanes) accounted for $2.3 \%$. The EO obtained from pasture plants contained the usual terpenes already encountered in pasture plants, milk, and cheese from the same region (Cornu et al., 2001, 2005; Tornambé et al., 2006).

\section{Trial 1: Milk Sensory Properties}

Only $38 \%$ of the assessors (23 correct answers out of 61 ) were able to distinguish EO1 milk from $\mathrm{C}$ milk $(P$ $>0.05$ ). The low concentration (EO1) seemed to be too low to be perceived by the assessors. Conversely, 69\% of the assessors (42 correct answers out of 61 ) perceived a difference $(P \leq 0.001)$ between $\mathrm{C}$ and EO10 milks. The 42 assessors with the correct answers scored the intensity of the difference at an average of 3.1 on a structured scale from 1 to 5 . Spontaneous attributes used to qualify the differences perceived were more "thyme" and "mint" odor and a stronger taste for EO10 milk. Moreover, assessors found the E010 milk sweeter. The unusual flavors described by the panelists were undoubtedly linked to the addition of EO. Therefore, the threshold concentration for the perception of the flavor linked to the EO addition was between 0.1 and $1.0 \mu \mathrm{L} / \mathrm{L}$. This result agrees with the findings of $\mathrm{Du}-$ broeucq et al. (2002). These authors did not show any influence on the sensory properties of milks through the enrichment of a hay-based diet with dried aromatic plants (Achillea millefolium or Meum athamanticum), even if this addition is known to increase the quantity of terpenes desorbing from milk (Viallon et al., 2000) up to a level similar to that of EO1. Dubroeucq et al. (2002) reported that the assessors were able to distinguish between the milk from hay- and mountain-diversified pastures, the latter is known to increase the quantity of terpenes desorbing from milk up to a level similar to that of EO10.

\section{Trial 2: Influence of EO Addition on Chemical and Sensory Properties of Cheese}

Milk Properties. The C, EO1, and EO30 milks used for cheese making had very similar fat, protein, and 
Table 1. Essential oil composition (percentage of the total ion count)

\begin{tabular}{|c|c|c|}
\hline Compounds & $\mathrm{KI}^{1}$ & $\%$ \\
\hline \multicolumn{3}{|l|}{ Ketones } \\
\hline Octanone-3 & 984 & 0.17 \\
\hline \multicolumn{3}{|l|}{ Aldehydes } \\
\hline Furancarboxaldehyde & 830 & 0.06 \\
\hline E-2-Hexenal & 852 & 0.01 \\
\hline Benzaldehyde & 961 & 0.03 \\
\hline Heptanal & 899 & 0.01 \\
\hline Benzeneacetaldehyde & 1,043 & 0.05 \\
\hline Nonanal & 1,101 & 0.25 \\
\hline \multicolumn{3}{|l|}{ Alcohols } \\
\hline Z-3-Hexenol & 855 & 0.06 \\
\hline E-2-Hexenol & 866 & 0.02 \\
\hline 1-Octen-3-ol & 978 & 0.26 \\
\hline Octanol-3 & 993 & 0.11 \\
\hline \multicolumn{3}{|l|}{ Esters } \\
\hline Salicylic acid methyl ester & 1,190 & 0.06 \\
\hline Benzoic acid benzyl ester & 1,762 & 0.13 \\
\hline Hexadecanoic acid methyl ester & 1,927 & 0.04 \\
\hline \multicolumn{3}{|l|}{ Alkanes } \\
\hline n C19H40 & 1,900 & 0.04 \\
\hline n C20H42 & 2,000 & 0.04 \\
\hline n $\mathrm{C} 21 \mathrm{H} 44$ & 2,100 & 0.18 \\
\hline n C23H48 & 2,300 & 0.28 \\
\hline n C25H52 & 2,500 & 0.19 \\
\hline n C27H56 & 2,700 & 0.10 \\
\hline n C29H60 & 2,900 & 0.16 \\
\hline \multicolumn{3}{|l|}{ Benzenic compound } \\
\hline Thymol methyl ether & 1,235 & 0.42 \\
\hline Carvacrol methyl ether & 1,244 & 0.65 \\
\hline Cuminaldehyde & 1,242 & 0.03 \\
\hline Thymol & 1,290 & 1.06 \\
\hline Carvacrol & 1,298 & 4.38 \\
\hline Eugenol & 1,356 & 0.33 \\
\hline Dill apiole & 1,622 & 5.04 \\
\hline \multicolumn{3}{|l|}{ Monoterpenes } \\
\hline Santolinatriene & 908 & 0.01 \\
\hline$\alpha$-Thujene & 931 & 0.03 \\
\hline$\alpha$-Pinene & 939 & 0.23 \\
\hline Camphene & 953 & 0.11 \\
\hline Sabinene & 976 & 0.28 \\
\hline$\beta$-Pinene & 980 & 0.74 \\
\hline Myrcene & 991 & 0.29 \\
\hline$\alpha$-Phellandrene & 1,005 & 0.68 \\
\hline$\alpha$-Terpinene & 1,018 & 0.26 \\
\hline Sylvestrene & 1,027 & 0.79 \\
\hline Z- $\beta$-Ocimene & 1,040 & 0.83 \\
\hline E- $\beta$-Ocimene & 1,050 & 2.58 \\
\hline$\gamma$-Terpinene & 1,062 & 1.91 \\
\hline Terpinolene & 1,088 & 3.10 \\
\hline \multicolumn{3}{|l|}{ Monoterpene derivatives } \\
\hline$\rho$-Cymene & 1,026 & 1.69 \\
\hline$\rho$-Cymenene & 1,089 & 0.24 \\
\hline Eucalyptol & 1,033 & 1.03 \\
\hline Z-Linalool oxide & 1,069 & 0.15 \\
\hline Linalool & 1,096 & 0.56 \\
\hline E-Thujone & 1,114 & 0.03 \\
\hline Chrysantenone & 1,123 & 0.09 \\
\hline Z- $\rho$-Menth-2-ene-1ol & 1,222 & 0.15 \\
\hline E- $\rho$-Menth-2-ene-1-ol & 1,141 & 0.14 \\
\hline Camphor & 1,146 & 1.63 \\
\hline Citonnellal & 1,153 & 0.07 \\
\hline Pinocarvone & 1,162 & 0.08 \\
\hline Cis-chrysanthenol & 1,164 & 0.40 \\
\hline Borneol & 1,165 & 1.21 \\
\hline Terpinen-4-ol & 1,177 & 1.13 \\
\hline$\rho$-Cymen-8-ol & 1,183 & 0.24 \\
\hline$\alpha$-Terpineol & 1,195 & 0.62 \\
\hline
\end{tabular}

Table 1 (Continued). Essential oil composition (percentage of the total ion count)

\begin{tabular}{|c|c|c|}
\hline Compounds & $\mathrm{KI}^{1}$ & $\%$ \\
\hline Myrtenol & 1,196 & 0.20 \\
\hline Fraganol & 1,212 & 0.58 \\
\hline Geraniol & 1,255 & 0.22 \\
\hline Acetic acid chrysanthenyl ester & 1,262 & 0.22 \\
\hline Acetic acid neryl ester & 1,361 & 0.13 \\
\hline Acetic acid carvacryl ester & 1,373 & 0.03 \\
\hline Acetic acid neryl ester & 1,371 & 0.11 \\
\hline \multicolumn{3}{|l|}{ Sesquiterpenes } \\
\hline$\gamma$-Elemene & 1,338 & 0.14 \\
\hline Isocomene & 1,386 & 0.32 \\
\hline$\alpha$-Copaene & 1,376 & 0.32 \\
\hline$\beta$-Bourbonene & 1,384 & 0.37 \\
\hline$\beta$-Elemene & 1,389 & 0.24 \\
\hline Sesquithujene & 1,399 & 0.07 \\
\hline$\beta$-Caryophyllene & 1,418 & 3.58 \\
\hline$\beta$-Copaene & 1,430 & 0.28 \\
\hline E- $\beta$-Farnesene $+\alpha$-humulene & 1,454 & 2.62 \\
\hline Germacrene-D & 1,480 & 9.22 \\
\hline$\gamma$-Muurolene & 1,492 & 0.66 \\
\hline Bicyclogermacrene & 1,494 & 1.71 \\
\hline$\alpha$-Farnesene & 1,508 & 0.93 \\
\hline$\beta$-Bisabolene & 1,509 & 1.86 \\
\hline$\delta$-Cadinene & 1,520 & 1.78 \\
\hline$\beta$-Sesquiphellandrene & 1,516 & 0.57 \\
\hline Cadina-1,4-diene & 1,523 & 0.15 \\
\hline$\alpha$-Cadinene & 1,538 & 0.24 \\
\hline \multicolumn{3}{|l|}{ Sesquiterpene derivatives } \\
\hline Albene & 1,154 & 0.02 \\
\hline E- $\beta$-Damascenone & 1,380 & 0.19 \\
\hline 4-(2,6,6-trimethylcyclohexa-1,3-dienyl)butan-2-one & 1,416 & 0.18 \\
\hline Nerolidol & 1,564 & 3.36 \\
\hline Caryophyllene oxide & 1,581 & 0.79 \\
\hline Cadinol-epi- $\alpha$ & 1,640 & 1.16 \\
\hline Muurolol-epi- $\alpha$ & 1,641 & 0.83 \\
\hline$\alpha$-Muurolol-epi- $\alpha$ & 1,641 & 0.34 \\
\hline$\alpha$-Cadinol & 1,653 & 1.80 \\
\hline$\alpha$-Bisabolol & 1,683 & 1.62 \\
\hline 2-Pentadecanone,6,10,14-trimethyl & 1,837 & 0.23 \\
\hline Total & & 75.36 \\
\hline
\end{tabular}

\footnotetext{
${ }^{1}$ Kovats index.
}

lactose contents, SCC, lipolysis, and spores of butyric acid bacteria (Table 2). The 3 milks also behaved similarly during acidification for the 2 temperature kinetics (Table 2). The latter result showed that even at the EO30 concentration, the acidification activity of the starters was not modified. In dairy products, the absence of influence of EO on microbial activity has not been reported previously. In other complex microbial ecosystems such as rumen fluid, some EO (e.g., cinnamon, anise, or garlic oils) have been shown to exert an influence on fermentation activities when added at concentrations (ranging from 0.2 to $2.0 \mathrm{mg} / \mathrm{L}$ ) slightly lower than EO30 (Calsamiglia et al., 2007). Nevertheless, the main active compounds of the EO studied by Calsamiglia et al. (2007) were not identified in the EO tested in this study.

Cheese Gross Composition and Sensory Properties. The chemical composition of the ripened cheeses 
Table 2. Composition and characteristics of milk in the vat

\begin{tabular}{|c|c|c|c|c|c|}
\hline \multirow[b]{2}{*}{ Item } & \multicolumn{3}{|c|}{ Treatment $^{1}$} & \multirow[b]{2}{*}{$P$-value ${ }^{2}$} & \multirow[b]{2}{*}{$\mathrm{RSD}^{3}$} \\
\hline & $\mathrm{C}$ & EO1 & EO30 & & \\
\hline \multicolumn{6}{|l|}{ Composition } \\
\hline Fat, $\mathrm{g} / \mathrm{L}$ & 38.7 & 38.9 & 38.4 & NS & 1.05 \\
\hline Protein, g/L & 31.8 & 31.9 & 31.7 & NS & 0.34 \\
\hline Lactose, $\mathrm{g} / \mathrm{L}$ & 48.7 & 48.8 & 48.6 & NS & 0.33 \\
\hline $\mathrm{SCC}, \mathrm{log} / \mathrm{mL}$ & 5.1 & 5.1 & 5.1 & NS & 4.60 \\
\hline FFA, mEq/100 $\mathrm{g}$ of fat & 0.53 & 0.58 & 0.53 & NS & 0.10 \\
\hline Spores of butyric acid bacteria, spores/L & 2,467 & 2,400 & 3,317 & NS & 992 \\
\hline \multicolumn{6}{|l|}{ Acidification properties } \\
\hline \multicolumn{6}{|l|}{ Variable temperature } \\
\hline $\mathrm{pH}$ at $\mathrm{t}=0$ & 6.66 & 6.67 & 6.65 & NS & 0.07 \\
\hline $\mathrm{pH}$ at $\mathrm{t}=24 \mathrm{~h}$ & 4.45 & 4.40 & 4.41 & NS & 0.07 \\
\hline $\mathrm{pH}$ at $\mathrm{t}=36 \mathrm{~h}$ & 4.38 & 4.34 & 4.38 & NS & 0.05 \\
\hline \multicolumn{6}{|l|}{ Constant temperature $\left(32^{\circ} \mathrm{C}\right)$} \\
\hline $\mathrm{pH}$ at $\mathrm{t}=0$ & 6.66 & 6.66 & 6.66 & NS & 0.05 \\
\hline $\mathrm{pH}$ at $\mathrm{t}=24 \mathrm{~h}$ & 4.61 & 4.62 & 4.86 & NS & 0.23 \\
\hline $\mathrm{pH}$ at $\mathrm{t}=36 \mathrm{~h}$ & 4.46 & 4.48 & 4.53 & NS & 0.05 \\
\hline
\end{tabular}

was not modified by the addition of EO except for chlorides, which were slightly higher $(P \leq 0.05)$ in the EO30 cheese than in the $\mathrm{C}$ cheese (Table 3 ).

The sensory properties of the C and EO1 cheeses were very similar (Table 4). None of the 38 attributes used to describe the cheese sensory characteristics differed significantly between EO1 and C cheeses. As stated for the sensory properties of milk, addition of $0.1 \mu \mathrm{L} / \mathrm{L}$ of EO seemed to be too low to exert any influence on the sensory properties of cheeses. Conversely, $\mathrm{C}$ and EO1 cheeses differed significantly from EO30 cheeses for 23 of the 38 attributes. The EO30 cheeses were characterized by their more intense odor and aroma $(P \leq 0.001)$ : they had more "mint" odor and "mint/ chlorophyll" and "thyme/oregano" aroma. The thyme

Table 3. Chemical characteristics of ripened cheeses

\begin{tabular}{|c|c|c|c|c|c|}
\hline \multirow{2}{*}{$\begin{array}{l}\text { Chemical } \\
\text { composition }^{1}\end{array}$} & \multicolumn{3}{|c|}{ Treatment $^{2}$} & \multirow[b]{2}{*}{$P$-value ${ }^{3}$} & \multirow[b]{2}{*}{$\mathrm{RSD}^{4}$} \\
\hline & $\mathrm{C}$ & EO1 & EO30 & & \\
\hline $\mathrm{DM}, \%$ & 63.2 & 63.7 & 63.0 & NS & 0.91 \\
\hline Fat/DM, \% & 52.4 & 51.9 & 52.0 & NS & 0.58 \\
\hline Chlorides, \% & $2.0^{\mathrm{a}}$ & $2.1^{\mathrm{ab}}$ & $2.1^{\mathrm{b}}$ & $*$ & 0.08 \\
\hline Calcium, \% & 0.7 & 0.7 & 0.7 & NS & 0.04 \\
\hline WSN/TN, \% & 16.8 & 18.9 & 17.4 & NS & 2.75 \\
\hline PTN/WSN, \% & 50.6 & 45.6 & 46.1 & NS & 7.34 \\
\hline $\mathrm{PTN} / \mathrm{TN}, \%$ & 8.4 & 8.4 & 8.0 & NS & 1.12 \\
\hline
\end{tabular}

\footnotetext{
${ }^{\mathrm{a}, \mathrm{b}}$ Means within a row with different superscripts differ $(P<0.05)$.

${ }^{1} \mathrm{WSN}=$ water-soluble nitrogen; $\mathrm{TN}=$ total nitrogen; $\mathrm{PTN}=$ phosphotungstic acid-soluble nitrogen.

${ }^{2}$ Treatments: $\mathrm{C}=$ control; $\mathrm{EO} 1=$ control milk $+0.1 \mu \mathrm{L} / \mathrm{L}$ of $\mathrm{EO}$; EO30 $=$ control milk $+3.0 \mu \mathrm{L} / \mathrm{L}$ of EO.

${ }^{3}$ Significance of difference: $* P \leq 0.05 ; \mathrm{NS}=P>0.05$.

${ }^{4}$ Residual standard deviation.
}

aroma could be due to $\delta$-cadinene and the mint aroma and odor to 1,8-cineole (eucalyptol), $\beta$-phellandrene, and methyl salicylate (Acree and Arn, 2004) added with the EO. All the other aroma and odor attributes scored lower in EO30 than in the $\mathrm{C}$ and EO1 cheeses. Because no effect was observed on the gross chemical composition of cheeses, it is reasonable to think that, at this concentration $(3.0 \mu \mathrm{L} / \mathrm{L})$, the very strong direct effect of $\mathrm{EO}$ on cheese flavor concealed the other perceptions that consequently received low scores. The EO30 cheeses had more astringent and persistent taste and they were less salty than the $\mathrm{C}$ and EO1 cheeses. The greater astringency, known to rely partly on phenolic compounds, could be due to the presence of thymol, carvacrol, and dill apiole. Although very low amounts were detected in the volatiles desorbing from cheeses, dill apiole may have been present in much greater proportions in the cheese because it was the second most abundant component of the EO. However, the dynamic headspace extraction performed to analyze terpenes in cheese was not well suited for molecules with such high retention indices.

Cheese Volatile Compounds. The volatile compounds desorbing from cheese were examined as extensively as possible to detect any difference linked to the addition of EO, which may reflect some perturbation of the microbial metabolism, even through compounds with no interest from the sensory point of view. One hundred fifty-three of the volatile compounds desorbing from cheeses are presented in Table 5. The most abundant compounds in total ion current (data not shown) were acetic acid, 2,3- and 1,3-butanediol, butanoic acid, acetoin (3-hydroxy-2-butanone), hexanoic acid, 2-buta- 
Table 4. Sensory characteristics of ripened cheeses (notes on a scale from 0 to 7 )

\begin{tabular}{|c|c|c|c|c|c|}
\hline \multirow[b]{2}{*}{ Item } & \multicolumn{3}{|c|}{ Treatment $^{1}$} & \multirow[b]{2}{*}{$P$-value ${ }^{2}$} & \multirow[b]{2}{*}{$\mathrm{RSD}^{3}$} \\
\hline & $\mathrm{C}$ & EO1 & EO30 & & \\
\hline \multicolumn{6}{|l|}{ Odor } \\
\hline Odor intensity & $3.9^{\mathrm{a}}$ & $4.1^{\mathrm{a}}$ & $4.7^{\mathrm{b}}$ & $* * *$ & 0.7 \\
\hline Butter & $2.3^{\mathrm{b}}$ & $2.5^{\mathrm{b}}$ & $1.1^{\mathrm{a}}$ & $* * *$ & 1.0 \\
\hline Fresh cream & $1.0^{\mathrm{b}}$ & $1.1^{\mathrm{b}}$ & $0.2^{\mathrm{a}}$ & $* * *$ & 1.0 \\
\hline Yogurt & 0.4 & 0.4 & 0.2 & NS & 0.9 \\
\hline Acidified cream & $1.3^{\mathrm{b}}$ & $1.0^{\mathrm{b}}$ & $0.3^{\mathrm{a}}$ & $* * *$ & 1.3 \\
\hline Cooked cheese & $1.5^{\mathrm{b}}$ & $1.5^{\mathrm{b}}$ & $0.6^{\mathrm{a}}$ & $* * *$ & 1.1 \\
\hline Vanilla & $1.1^{\mathrm{b}}$ & $1.3^{\mathrm{b}}$ & $0.3^{\mathrm{a}}$ & $* * *$ & 1.0 \\
\hline Brioche & $1.5^{\mathrm{b}}$ & $1.4^{\mathrm{b}}$ & $0.6^{\mathrm{a}}$ & $* * *$ & 1.1 \\
\hline Hazelnut & 0.2 & 0.3 & 0.1 & NS & 0.6 \\
\hline Meat & $0.7^{\mathrm{b}}$ & $0.5^{\mathrm{b}}$ & $0.1^{\mathrm{a}}$ & $* *$ & 1.0 \\
\hline Mint & $0.1^{\mathrm{a}}$ & $0.1^{\mathrm{a}}$ & $0.6^{\mathrm{b}}$ & $* * *$ & 0.8 \\
\hline \multicolumn{6}{|l|}{ Aroma } \\
\hline Aroma intensity & $3.8^{\mathrm{a}}$ & $3.6^{\mathrm{a}}$ & $5.4^{\mathrm{b}}$ & $* * *$ & 0.9 \\
\hline Butter & $1.7^{\mathrm{b}}$ & $1.6^{\mathrm{b}}$ & $0.9^{\mathrm{a}}$ & $* * *$ & 1.0 \\
\hline Fresh cream & 0.4 & 0.4 & 0.1 & NS & 0.8 \\
\hline Cooked cheese & $1.6^{\mathrm{b}}$ & $1.3^{\mathrm{b}}$ & $0.5^{\mathrm{a}}$ & $* * *$ & 1.0 \\
\hline Lactic acid & $1.3^{\mathrm{b}}$ & $1.6^{\mathrm{b}}$ & $0.5^{\mathrm{a}}$ & $* * *$ & 1.1 \\
\hline Garlic & $0.9^{b}$ & $0.9^{\mathrm{b}}$ & $0.5^{\mathrm{a}}$ & $*$ & 0.9 \\
\hline Mushrooms/underwood & 0.5 & 0.5 & 0.6 & NS & 1.1 \\
\hline Grilled onion & $0.7^{\mathrm{b}}$ & $0.5^{\mathrm{b}}$ & $0.2^{\mathrm{a}}$ & $* * *$ & 0.7 \\
\hline Stubble & $0.3^{\mathrm{b}}$ & $0.4^{\mathrm{b}}$ & $0.0^{\mathrm{a}}$ & $* *$ & 0.6 \\
\hline Meat & $1.2^{\mathrm{b}}$ & $1.3^{\mathrm{b}}$ & $0.1^{\mathrm{a}}$ & $* * *$ & 1.1 \\
\hline Cheese mites & $0.4^{\mathrm{b}}$ & $0.3^{\mathrm{b}}$ & $0.0^{\mathrm{a}}$ & $* * *$ & 0.5 \\
\hline Mint/chlorophyll & $0.1^{\mathrm{a}}$ & $0.3^{\mathrm{a}}$ & $4.8^{\mathrm{b}}$ & $* * *$ & 1.0 \\
\hline Thyme/oregano & $0.1^{\mathrm{a}}$ & $0.1^{\mathrm{a}}$ & $3.1^{\mathrm{b}}$ & $* * *$ & 1.1 \\
\hline \multicolumn{6}{|l|}{ Taste } \\
\hline Salt & $3.0^{\mathrm{b}}$ & $3.2^{\mathrm{b}}$ & $2.5^{\mathrm{a}}$ & $* *$ & 1.0 \\
\hline Sweet & 0.3 & 0.3 & 0.4 & NS & 0.3 \\
\hline Acid & 2.3 & 2.1 & 2.3 & NS & 1.0 \\
\hline Bitter & 0.7 & 0.5 & 0.8 & NS & 0.9 \\
\hline Piquant & 1.6 & 1.3 & 1.5 & NS & 1.0 \\
\hline Astringent & $0.5^{\mathrm{ab}}$ & $0.4^{\mathrm{a}}$ & $0.7^{\mathrm{b}}$ & $* * *$ & 0.8 \\
\hline Persistent & $4.0^{\mathrm{a}}$ & $4.0^{\mathrm{a}}$ & $5.1^{\mathrm{b}}$ & $* * *$ & 1.0 \\
\hline \multicolumn{6}{|l|}{ Texture } \\
\hline Elastic & 4.6 & 4.3 & 4.7 & NS & 0.9 \\
\hline Firm & 4.0 & 4.4 & 4.2 & NS & 0.8 \\
\hline Crumbly & 3.4 & 3.3 & 3.5 & NS & 0.9 \\
\hline Sticky & 3.8 & 3.9 & 3.5 & NS & 1.0 \\
\hline Gritty & 4.1 & 4.1 & 4.1 & NS & 0.8 \\
\hline Melting & 4.5 & 4.6 & 4.6 & NS & 0.8 \\
\hline Mellow & 4.3 & 4.1 & 4.2 & NS & 0.7 \\
\hline
\end{tabular}

${ }^{\mathrm{a}, \mathrm{b}}$ Means within a row with different superscripts differ $(P<0.05)$

${ }^{1}$ Treatments: $\mathrm{C}=$ control; $\mathrm{EO} 1=$ control milk $+0.1 \mu \mathrm{L} / \mathrm{L}$ of $\mathrm{EO}$; $\mathrm{EO} 30=$ control milk $+3.0 \mu \mathrm{L} / \mathrm{L}$ of $\mathrm{EO}$.

${ }^{2}$ Significance of difference: $* P \leq 0.05$; ** $P \leq 0.01$; *** $P \leq 0.001$; NS $=$ $P>0.05$.

${ }^{3}$ Residual standard deviation.

nol, and 2-butanone. These main compounds desorbing from the cheeses were previously reported by Callon et al. (2005) for Salers cheese, and by De Freitas et al. (2005) for Cantal cheese. Except for 1,3- and 2,3-butanediol, the volatile profile of our cheeses was close to that of Salers cheese (a farmhouse raw milk cheese very similar to Cantal) with acetic, butanoic, and hexanoic acids, acetoin, 2-butanone, and 2-butanol being among the major compounds.

Among the 152 compounds desorbing from cheeses, 41 had been added with the EO. In contrast, 54 com- pounds of the EO were not found in the cheese. The 15 compounds having retention indices greater than 1,620 in the cheese were not analyzed. Most of the other 39 were minor components of the EO. Nevertheless, $\beta$ bisabolene, bicyclogermacrene, nerolidol, thymol, and carvacrol together represented $12.4 \%$ of the total area in the EO chromatogram.

Sixty compounds were significantly affected by treatment. Among them, 40 had been added with the EO and logically were much greater in EO30 than in C (average enrichment of 270 from $\mathrm{C}$ to EO30 for compounds present in $\mathrm{C}$ ). Thirty-one of these 40 compounds were not significantly greater in EO1 than in C, even though the average enrichment from $\mathrm{C}$ to EO1 was 10 (for compounds present in C). As is usually observed, the areas of the most important peaks exhibited large variation among cheeses. This variability was observed also for the compounds added with the EO at a high concentration (EO30). As a result, the statistical analysis failed to demonstrate any significant differences between the $\mathrm{C}$ and $\mathrm{EO} 1$ cheeses for 31 compounds. Indeed, the same statistical analysis performed on $\mathrm{C}$ and EO1 values alone (not shown) presented significant differences for the 19 added and recovered monoterpenoids.

The other 20 compounds significantly affected by the treatment had not been added with the EO or at least were not included in the 95 most important compounds of the EO. These included 11 terpenoids, 3 alcohols, 1 ketone, 1 ester, 1 hydrocarbon, and 3 unidentified compounds. Most of these compounds were present at significantly greater concentrations in EO30 than in C and EO1 and followed the pattern of the added compounds. These compounds may have resulted directly or indirectly from the addition of the EO. Nevertheless, propanol, 2-butanol, and 3-heptanone are particularly interesting because they did not follow the pattern of the added compounds. The concentration of propanol was greater and that of 3-heptanone lower in the EO1 than in the $\mathrm{C}$ or EO30 cheeses and the concentration of 2-butanol was greater in $\mathrm{C}$ than in EO1 and EO30. These products are produced from lipid catabolism resulting from the action of the native or microbial enzymes (Marilley and Casey, 2004). Callon et al. (2005) observed 2-butanol to be significantly affected by changes in the indigenous microflora such as the facultative heterofermentative lactobacilli population of the raw milk. Therefore, it can be hypothesized that the addition of EO slightly modified the metabolism of some lactobacilli. Nevertheless, this possible effect was subtle and did not influence the proteolysis or the flavor of the cheese. This slight influence of EO on the activity of cheese microflora has not previously been described in the literature. Because the EO used in this study contained a variety of compounds, it is not possible to 
Table 5. Volatile compounds desorbing from the cheeses ${ }^{1}$

\begin{tabular}{|c|c|c|c|c|c|c|c|}
\hline \multirow[b]{2}{*}{$\mathrm{LRI}^{2}$} & \multirow[b]{2}{*}{ Compound } & \multirow[b]{2}{*}{ Ion } & \multicolumn{3}{|c|}{ Treatment $^{3}$} & \multirow[b]{2}{*}{$P$-value ${ }^{4}$} & \multirow[b]{2}{*}{$\mathrm{RSD}^{5}$} \\
\hline & & & $\mathrm{C}$ & EO1 & EO30 & & \\
\hline \multicolumn{8}{|c|}{ Alcohols $(\mathrm{n}=23)$} \\
\hline 480 & Ethanol & 45 & 10.47 & 14.06 & 16.31 & NS & 7.72 \\
\hline 504 & 2-Propanol & 45 & 29.84 & 42.58 & 27.61 & NS & 26.07 \\
\hline 557 & 1-Propanol & 59 & $5.70^{\mathrm{a}}$ & $96.96^{\mathrm{b}}$ & $13.05^{\mathrm{a}}$ & $*$ & 53.79 \\
\hline 605 & 2-Butanol & 59 & $260.79^{\mathrm{b}}$ & $97.03^{\mathrm{a}}$ & $77.63^{\mathrm{a}}$ & $*$ & 127.36 \\
\hline 627 & 2-Methyl propanol & 74 & 1.69 & 1.70 & 2.23 & NS & 1.29 \\
\hline 667 & 1-Butanol & 56 & 3.26 & 3.70 & 6.64 & NS & 6.35 \\
\hline 701 & 2-Pentanol & 45 & 31.06 & 37.14 & 24.97 & NS & 31.04 \\
\hline 731 & 3-Methyl-3-buten-1-ol & 68 & 1.63 & 1.61 & 1.92 & NS & 0.80 \\
\hline 735 & 3-Methyl-1-butanol & 57 & 10.58 & 13.52 & 10.20 & NS & 9.08 \\
\hline 738 & 2-Methyl-1-butanol & 57 & 5.11 & 6.52 & 5.72 & NS & 3.71 \\
\hline 767 & 1-Pentanol & 55 & 1.34 & 1.18 & 0.91 & NS & 0.41 \\
\hline 776 & 2-Methyl-2-buten-1-ol & 86 & 0.75 & 0.70 & 0.81 & NS & 0.16 \\
\hline 857 & Cis-3-hexenol $^{6}$ & 67 & $0.07^{\mathrm{a}}$ & $0.02^{\mathrm{a}}$ & $0.37^{\mathrm{b}}$ & $* * *$ & 0.11 \\
\hline 869 & 1-Hexanol & 56 & 0.97 & 3.51 & 1.98 & NS & 3.22 \\
\hline 899 & 2-Heptanol & 45 & 2.52 & 5.95 & 4.02 & NS & 5.49 \\
\hline 979 & 1 -Octen-3-ol ${ }^{6}$ & 72 & $0.05^{\mathrm{a}}$ & $0.11^{\mathrm{a}}$ & $1.62^{\mathrm{b}}$ & $* * *$ & 0.10 \\
\hline 993 & 3 -Octanol ${ }^{6}$ & 59 & $0.08^{\mathrm{a}}$ & $0.15^{\mathrm{a}}$ & $1.33^{\mathrm{b}}$ & $* * *$ & 0.34 \\
\hline 1077 & 1-Octanol & 84 & $0.10^{\mathrm{a}}$ & $0.00^{\mathrm{a}}$ & $0.32^{\mathrm{b}}$ & $* *$ & 0.34 \\
\hline 750 & 1,2-Propanediol & 75 & 0.26 & 0.27 & 0.22 & NS & 0.12 \\
\hline 784 & 2,3-Butanediol & 45 & 630.74 & 613.39 & 539.43 & NS & 98.36 \\
\hline 798 & 1,3-Butanediol & 45 & 552.64 & 609.88 & 566.00 & NS & 96.29 \\
\hline 905 & 2-Butoxy-ethanol & 43 & 0.56 & 0.27 & 0.36 & NS & 0.41 \\
\hline 1129 & 2-Phenylethanol & 122 & 0.26 & 0.55 & 0.27 & NS & 0.42 \\
\hline \multicolumn{8}{|c|}{ Aldehydes $(\mathrm{n}=5)$} \\
\hline 653 & 3-Methylbutanal & 86 & 0.26 & 0.13 & 0.22 & NS & 0.20 \\
\hline 696 & Pentanal & 44 & 1.17 & 1.11 & 1.23 & NS & 0.29 \\
\hline 830 & Furancarboxaldehyde 6 & 96 & 0.07 & 0.07 & 0.06 & NS & 0.04 \\
\hline 900 & Heptanal $^{6}$ & 86 & 0.24 & 0.23 & 0.25 & NS & 0.06 \\
\hline 967 & Benzaldehyde $^{6}$ & 105 & 0.84 & 0.81 & 0.88 & NS & 0.18 \\
\hline \multicolumn{8}{|c|}{ Ketones $(\mathrm{n}=11)$} \\
\hline 500 & 2-Propanone & 58 & 1.68 & 1.68 & 1.21 & NS & 0.44 \\
\hline 600 & 2-Butanone & 72 & 102.52 & 45.46 & 54.96 & NS & 48.12 \\
\hline 685 & 2-Pentanone & 86 & 24.71 & 30.07 & 14.87 & NS & 22.75 \\
\hline 885 & 3-Heptanone & 114 & $0.02^{\mathrm{b}}$ & $0.01^{\mathrm{a}}$ & $0.02^{\mathrm{b}}$ & $*$ & 0.006 \\
\hline 889 & 2-Heptanone & 114 & 2.76 & 6.49 & 2.44 & NS & 4.62 \\
\hline 984 & $3-$ Octanone ${ }^{6}$ & 72 & $0.08^{\mathrm{a}}$ & $0.18^{\mathrm{a}}$ & $3.97^{\mathrm{b}}$ & $* * *$ & 0.47 \\
\hline 1100 & 2-Nonanone & 58 & 2.49 & 7.61 & 2.51 & NS & 7.11 \\
\hline 1295 & 2-Undecanone & 58 & 0.34 & 0.50 & 0.36 & NS & 0.21 \\
\hline 591 & 2,3-Butanedione & 86 & 51.75 & 44.52 & 57.83 & NS & 27.90 \\
\hline 666 & 1-Hydroxypropanone & 74 & 0.53 & 0.62 & 1.03 & NS & 0.57 \\
\hline 710 & 3-Hydroxy-2-butanone & 88 & 269.66 & 297.19 & 404.69 & NS & 200.25 \\
\hline \multicolumn{8}{|c|}{ Acids ( $\mathrm{n}=13$ ) } \\
\hline 523 & Formic acid & 45 & 8.87 & 12.06 & 9.74 & NS & 3.71 \\
\hline 647 & Acetic acid & 60 & 1076.70 & 1225.07 & 1129.36 & NS & 200.68 \\
\hline 688 & Propanoic acid & 74 & 5.60 & 7.06 & 4.89 & NS & 2.43 \\
\hline 754 & 2-Methylpropanoic acid & 73 & 2.92 & 3.58 & 2.39 & NS & 1.41 \\
\hline 814 & Butanoic acid & 60 & 545.17 & 606.99 & 535.36 & NS & 172.42 \\
\hline 846 & 3-Methylbutanoic acid & 60 & 8.57 & 9.58 & 9.15 & NS & 3.60 \\
\hline 852 & 2-Methylbutanoic acid & 74 & 1.32 & 1.52 & 1.35 & NS & 0.56 \\
\hline 879 & Pentanoic acid & 60 & 9.53 & 11.88 & 9.19 & NS & 3.40 \\
\hline 984 & Hexanoic acid & 60 & 167.51 & 195.96 & 158.61 & NS & 50.94 \\
\hline 1074 & Heptanoic acid & 60 & 9.63 & 11.93 & 25.37 & NS & 22.61 \\
\hline 1118 & 2-Ethylhexanoic acid & 73 & 1.04 & 1.33 & 1.05 & NS & 0.39 \\
\hline 1625 & Dodecanoic acid & 60 & 0.23 & 0.42 & 0.07 & NS & 0.49 \\
\hline 1230 & 4-Hydroxybenzoic acid & 94 & 0.29 & 0.40 & 0.20 & NS & 0.29 \\
\hline \multicolumn{8}{|c|}{ Esters $(\mathrm{n}=12)$} \\
\hline 615 & Acetic acid ethyl ester & 88 & 2.19 & 0.83 & 1.27 & NS & 1.71 \\
\hline 721 & Butanoic acid methyl ester & 87 & 0.11 & 0.10 & 0.12 & NS & 0.14 \\
\hline 801 & Butanoic acid ethyl ester & 85 & $2.13^{\mathrm{a}}$ & $2.97^{\mathrm{ab}}$ & $3.94^{\mathrm{b}}$ & $*$ & 1.17 \\
\hline 875 & Acetic acid 3-methylbutyl ester & 87 & 0.32 & 0.58 & 0.48 & NS & 0.35 \\
\hline 923 & Hexanoic acid methyl ester & 74 & 0.81 & 1.81 & 1.03 & NS & 1.54 \\
\hline 996 & Hexanoic acid ethyl ester & 88 & 8.24 & 11.86 & 9.22 & NS & 3.20 \\
\hline 1059 & Butanoic acid 3-methylbutyl ester & 71 & 0.11 & 0.43 & 0.13 & NS & 0.42 \\
\hline 1195 & Octanoic acid ethyl ester & 88 & 0.92 & 1.38 & 1.01 & NS & 0.51 \\
\hline
\end{tabular}


Table 5 (Continued). Volatile compounds desorbing from the cheeses ${ }^{1}$

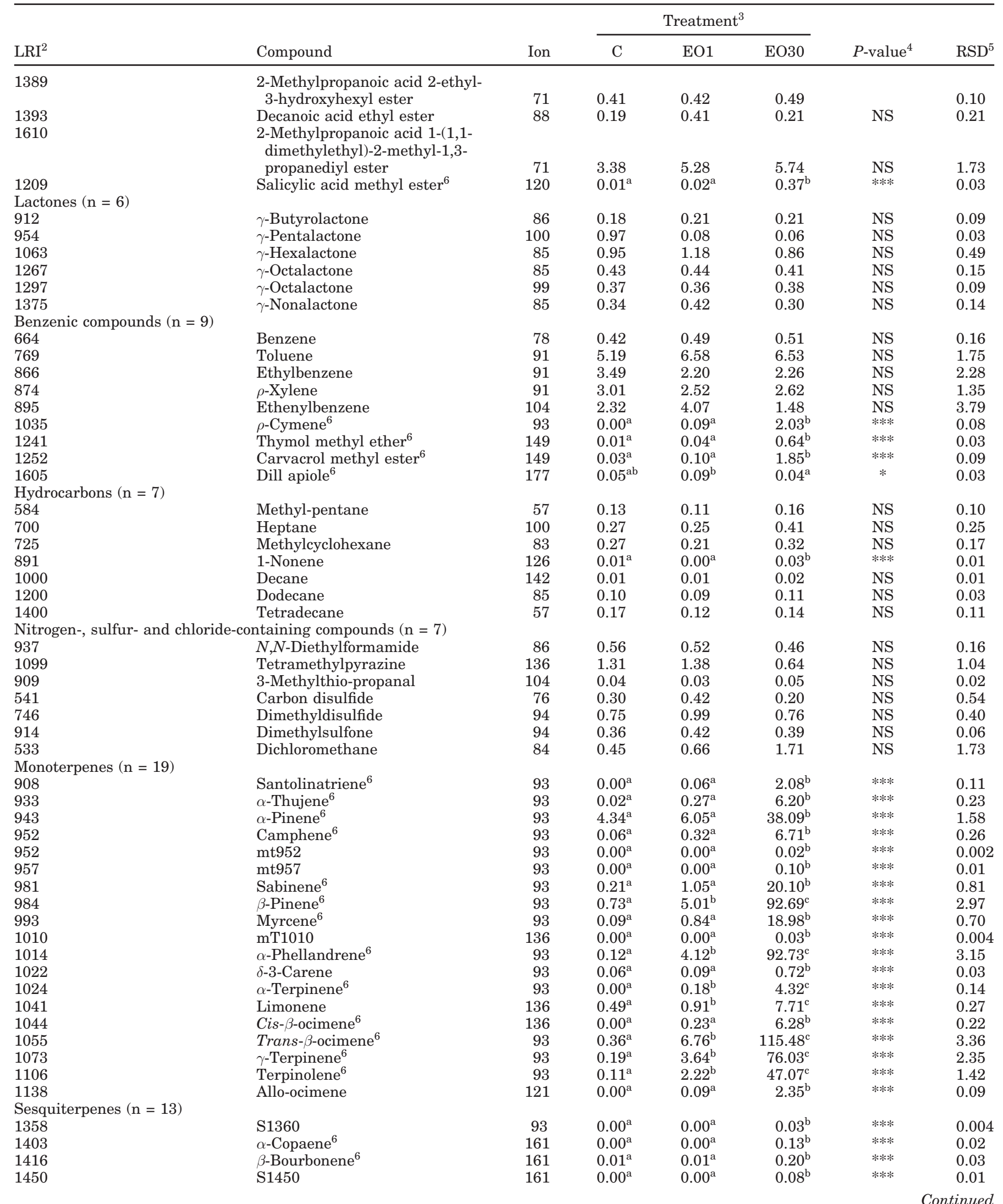


Table 5 (Continued). Volatile compounds desorbing from the cheeses ${ }^{1}$

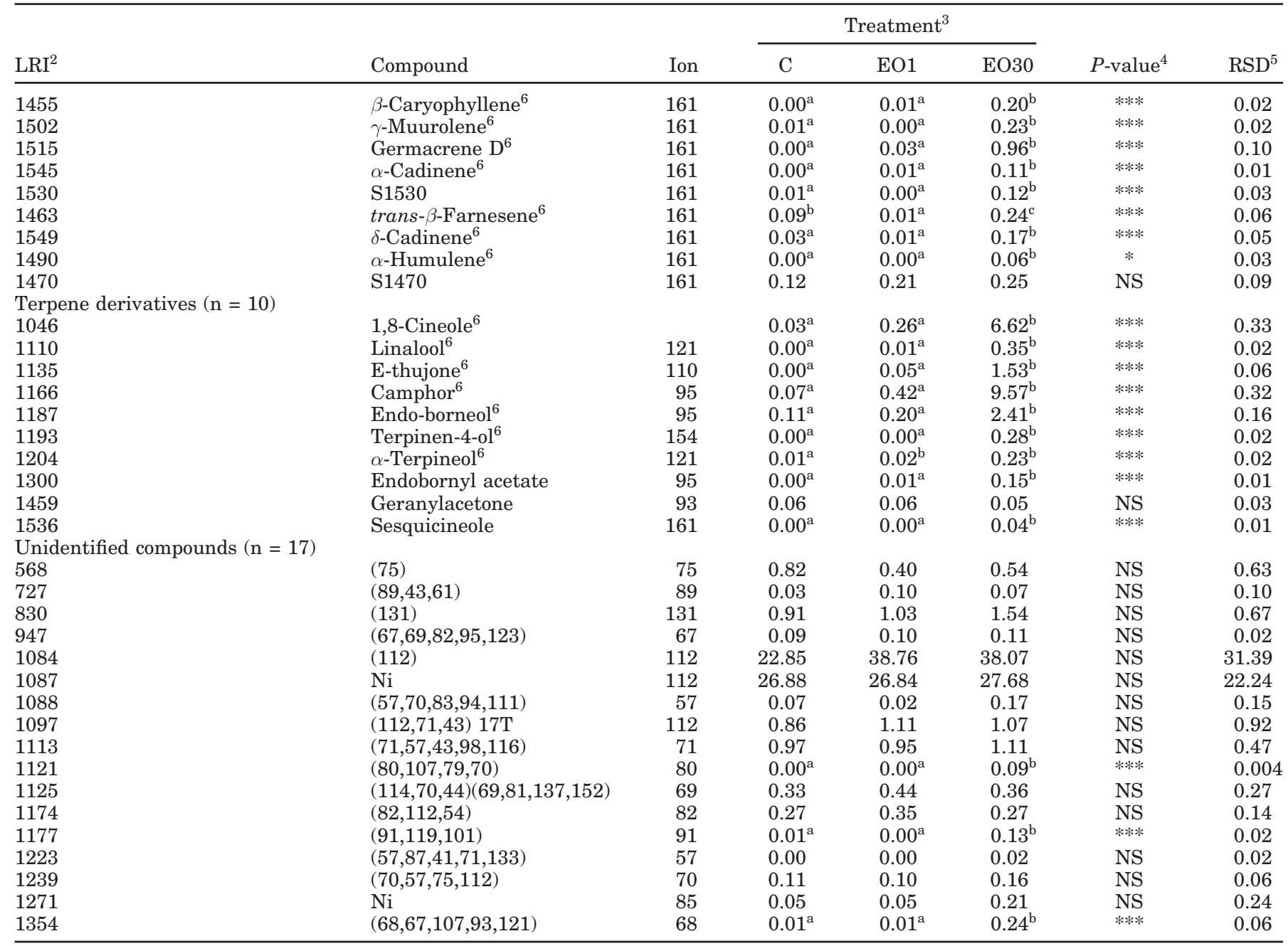

${ }^{\text {a-d }}$ Means within a row with different superscripts differ $(P<0.05)$.

${ }^{1}$ Values reported are the mean area (arbitrary area unit $\times 10^{-6}$ ) of the specified ion for 6 cheeses from each treatment.

${ }^{2} \mathrm{LRI}=$ experimental linear retention indices.

${ }^{3}$ Treatments: $\mathrm{C}=$ control; EO1 $=$ control milk $+0.1 \mu \mathrm{L} / \mathrm{L}$ of EO; EO30 = control milk $+3.0 \mu \mathrm{L} / \mathrm{L}$ of EO.

${ }^{4}$ Significance of difference: $* P \leq 0.05 ; * * P \leq 0.01 ; * * * P \leq 0.001 ; \mathrm{NS}=P>0.05$.

${ }^{5}$ Residual standard deviation.

${ }^{6}$ Compounds added with the essential oil.

identify the active compounds. Nevertheless, some of the most important compounds of the EO (e.g., thymol, carvacrol or terpinen-4-ol) have recognized antimicrobial properties (Calsamiglia et al., 2007) even if their activity, when added alone, in complex microbial ecosystems (i.e., in rumen) was shown only at concentrations greater than $50 \mathrm{mg} / \mathrm{L}$, which is much greater than the maximum concentration tested in this study.

Our results suggest that the influence of the botanical composition of the forages fed to the animals on the sensory properties of Cantal type cheeses is not (or is only slightly) linked to the terpenes arising from consumption of aromatic plants. This result is not in accordance with those obtained by other authors (Buchin et al., 1999; Bugaud et al., 2001b) who observed negative correlations between cheese terpenes and alcohols, esters, and sulfur compounds resulting from the breakdown of sulfur amino acids by microbial enzymes. First, this discrepancy may be linked to the cheese model chosen in the present study, an uncooked pressed cheese, whereas the results suggesting an inhibitory action of terpenes on cheese microorganisms were obtained on semicooked or cooked cheeses. Second, the effect of EO addition is probably different from that of the plants grazed on the grassland. Indeed, the terpenes ingested by cows are known to have an influence on 
the rumen microflora: they affect, in particular, protein degradation and volatile fatty acid production (Calsamiglia et al., 2007), which may result in milk compositional changes due to the nutrient flow out of the rumen. In addition, other dicotyledonous plant compounds such as phenols are known to be partially transferred into the milk (Sakakibara et al., 2004). Those nonvolatile compounds were not addressed in this experiment. It would be interesting to investigate their possible involvement in the links between cheese sensory properties and pasture botanical composition.

\section{CONCLUSIONS}

When EO was added at a concentration chosen so that the terpenes desorbing from milk correspond to the terpenes desorbing naturally from milk from cows fed a diversified hay (EO1), the EO seemed to be only marginally involved in the production of propanol, 2butanol, and 3-heptanone from lipid catabolism by microorganisms. This effect had no consequence for cheese sensory properties. Even when EO was added at a much greater concentration chosen so that the terpenes desorbing from milk were greater than the maximum terpenes desorbing naturally from milk produced from cows fed a diversified pasture, the EO had a marginal influence on the production of volatile compounds by the microorganism activity. At those concentrations (1.0 and $3.0 \mu \mathrm{L} / \mathrm{L}$ ), the great influence of EO on milk and cheese sensory properties is a direct effect of EO. It would be interesting to investigate the influence of intermediate concentrations of EO. Nevertheless, with the current results, we can conclude that a possible indirect influence of terpenes (via the antimicrobial activity of terpenes) is not, or is only marginally, involved in the explanation of the influence of the botanical composition of the meadows on the sensory properties of pressed cheeses.

\section{ACKNOWLEDGMENTS}

We wish to thank all those who helped in this trial, particularly Isabelle Constant (INRA) and Olivier Troquier (INRA) for their technical assistance, René Lavigne (INRA) for the cheesemaking, and Hervé Dubroeucq (INRA) for milk triangular test organization.

\section{REFERENCES}

Acree, T., and H. Arn. 2004. Flavornet and human odor space. http:// www.flavornet.org/flavornet.html

Adams, R. P. 1995. Identification of EO components by gas chromatography/mass spectroscopy. Allured Publishing Corporation, Carol Stream, IL.

AFNOR. 1983. Sensory Analysis. Methodology. Triangle Test. Standard NF V 09-013. Association Française de Normalisation, La Plaine St-Denis, France.
Ardö, Y. 1999. Evaluating proteolysis by analysing the N content of cheese fractions. FIL-IDF Bull. 337:4-9.

Bosset, J. O., B. Jeangros, T. Berger, U. Butikofer, M. Collomb, R. Gauch, P. Lavanchy, J. Scehovic, J. Troxler, and R. Sieber. 1999. Comparison of Gruyere-type hard cheese, produced in highland and lowland areas. Rev. Suisse d'Agric. 31:17-22.

Buchin, S., B. Martin, D. Dupont, A. Bornard, and C. Achilleos. 1999. Influence of the composition of Alpine highland pasture on the chemical, rheological and sensory properties of cheese. J. Dairy Res. 66:579-588.

Bugaud, C., S. Buchin, J. B. Coulon, A. Hauwuy, and D. Dupont. 2001a. Influence of the nature of alpine pastures on plasmin activity, fatty acid and volatile compound composition of milk. Lait 81:401-414.

Bugaud, C., S. Buchin, A. Hauwuy, and J. B. Coulon. 2001b. Relationships between flavour and chemical composition of Abondance cheese derived from different types of pastures. Lait 81:757-773.

Burt, S. 2004. Essential oils: Their antibacterial properties and potential application in food - a review. Int. J. Food Microbiol. 94:223-253.

Callon, C., J. L. Berdagué, E. Dufour, and M. C. Montel. 2005. The effect of raw milk microbial flora on the sensory characteristics of Salers-type cheeses. J. Dairy Sci. 88:3840-3850.

Calsamiglia, S., M. Busquet, P. W. Cardozo, L. Castillejos, and A. Ferret. 2007. Essential oils as modifiers of rumen microbial fermentation. J. Dairy Sci. 90:2580-2595.

Carpino, S., S. Mallia, S. La Terra, C. Melilli, G. Licita, T. E. Acree, D. M. Barbano, and P. J. Van Soest. 2004. Composition and aroma compounds of Ragusano cheese: Native pasture and total mixed rations. J. Dairy Sci. 87:816-830.

Cornu, A., A. P. Carnat, B. Martin, J. B. Coulon, J. L. Lamaison, and J. L. Berdagué. 2001. Solid phase microextraction of volatile components from natural grassland plants. J. Agric. Food Chem. $49: 203-209$

Cornu, A., N. Kondjoyan, B. Martin, I. Verdier-Metz, P. Pradel, J. L. Berdagué, and J. B. Coulon. 2005. Terpene profiles in Cantal and Saint-Nectaire-type cheese made from raw or pasteurised milk. J. Sci. Food Agric. 85:2040-2046.

Corrieu, G., H. Spinnler, D. Picque, and Y. Jomier. 1989. Method of revealing and monitoring the acidifying activity of fermentation agents in fermentation vats and devices for implementing it. French Patent FR 2629612.

De Freitas, I., N. Pinon, C. Lopez, A. Thierry, J. L. Maubois, and S. Lortal. 2005. Microstructure, physicochemistry, microbial populations and aroma compounds of ripened Cantal cheeses. Lait 85:453-468.

Dubroeucq, H., B. Martin, A. Ferlay, P. Pradel, I. Verdier-Metz, Y. Chillard, J. Agabriel, and J. B. Coulon. 2002. Cow's feeding may modify sensory properties of milk. Renc. Rech. Rumin. 9:351-354.

Dumont, J. P., and J. Adda. 1978. Occurrence of sesquiterpenes in mountain cheese volatiles. J. Agric. Food Chem. 26:364-367.

Hammer, K. A., C. F. Carson, and T. V. Rilevy. 1999. Antimicrobial activity of essential oils and other plant extracts. J. Appl. Microbiol. 86:985-990.

IDF. 1997. Determination of fat content: General guidance on the use of butyrometric methods (milk and milk products). Standard 152A. Int. Dairy Fed., Brussels, Belgium.

Jellema, A. 1991. Determination of free fatty acids in milk and milk products. Bull. Int. Dairy Fed., no 265. Int. Dairy Fed., Brussels, Belgium.

Kondjoyan, N., and J. L. Berdagué. 1996. A compilation of relative retention indices for the analysis of aromatic compounds, Laboratoire Flaveur Publisher, INRA, Clermont-Ferrand, France.

Mariaca, R. G., T. F. H. Berger, R. Gauch, M. I. Imhof, B. Jeangros, and J. O. Bosset. 1997. Occurrence of volatile mono- and sesquiterpenoids in highland and lowland plant species as possible precursors for flavor compounds in milk and dairy products. J. Agric. Food Chem. 45:4423-4434.

Marilley, L., and M. G. Casey. 2004. Flavours of cheese products: Metabolic pathways, analytical tools and identification of producing strains. Int. J. Food Microbiol. 90:139-159. 
Martin, B., S. Buchin, and A. Hauwuy. 2005b. Influence of the botanical composition of the highland pastures on the sensory characteristics of the Beaufort cheeses. Sci. Aliments 25:67-75.

Martin, B., I. Verdier-Metz, S. Buchin, C. Hurtaud, and J. B. Coulon. $2005 \mathrm{a}$. How do the nature of forages and pasture diversity influence the sensory quality of dairy livestock products? Anim. Sci. 81:205-212.

McLafferty, F. W., and D. B. Stauffer. 1989. The Wiley NBS Registry of Mass Spectral Data. 2nd ed. John Wiley and Son, New York, NY.

Moio, L., L. Rillo, A. Ledda, and F. Addeo. 1996. Odorous constituents of ovine milk in relationship to diet. J. Dairy Sci. 79:1322-1331.

NIST/EPA/NIH. 1996. Mass spectral database, standard references database program of the National Institute of Standards and Technology (NIST). Version 1.5 for PC. www.nist.gov/data/ nist1a.html.
Sakakibara, H., D. Viala, A. Ollier, A. Combeau, and J. M. Besle. 2003. Isoflavones in several clover species and in milk from goats fed clovers. Biofactors 22:237-239.

Tornambé, G., A. Cornu, P. Pradel, N. Kondjoyan, A. P. Carnat, M. Petit, and B. Martin. 2006. Changes in terpene content in milk from pasture-fed cows. J. Dairy Sci. 89:2634-2648.

Verdier-Metz, I., J. B. Coulon, P. Pradel, C. Viallon, H. Albouy, and J. L. Berdagué. 2000. Effect of the botanical composition of hay and casein genetic variants on the chemical and sensory characteristics of ripened Saint-Nectaire type cheeses. Lait 80:361-370.

Viallon, C., B. Martin, I. Verdier-Metz, P. Pradel, J. P. Garel, J. B. Coulon, and J. L. Berdagué. 2000. Transfer of monoterpenes and sesquiterpenes from forages into milk fat. Lait 80:635-641.

Viallon, C., I. Verdier-Metz, C. Denoyzer, P. Pradel, J. B. Coulon, and J. L. Berdagué. 1999. Desorbed terpenes and sesquiterpenes from forages and cheeses. J. Dairy Sci. 66:319-326. 